\title{
Analysis of learning anxiety among senior high school students
}

\author{
Taty Taty $^{\left.1^{*}\right)}$ \\ ${ }^{1}$ Universitas PGRI Palembang, Indonesia \\ ${ }^{*}$ Corresponding author, $\equiv$ e-mail: tattyfauzi62@gmail.com
}

\begin{abstract}
Learning is the primary task of every student. However, there are many factors responsible for the success or failure such as anxiety, which is the unpleasant feeling of worry, concern, and fear. Therefore this study aims to measure students' anxiety levels in learning and determine efforts to overcome this condition. This is a quantitative descriptive study, with data collected from 192 students using anxiety instruments. The results showed that most students' anxiety levels were in the normal category; this is because the majority chooses to confide in their close friends.
\end{abstract}

Keywords: Learning anxiety, counseling, student.

How to Cite: Taty, T. (2020). Analysis of Learning Anxiety Condition Among Senior High School Student. COUNS-EDU: The International Journal of Counseling and Education, 5(1), 39-45. DOI:10.23916/0020200526720

This is an open access article distributed under the Creative Commons Attribution License, which permits unrestricted use, distribution, and reproduction in any medium, provided the original work is properly cited. (C2020 by author.

\section{Introduction}

Adolescence is a period of transition from childhood to early adulthood (Copeland et al., 2013). It comprises of various types of biological, cognitive, social, and emotional changes(Friedman et al., 2016; Network, 2005). In addition, subjects become more complex and specific as children transition into adolescence in senior high schools, compared to kindergarten, elementary, and junior schools (Efrila, 2020). At this stage, unresolved problems and pressures experienced by students cause anxiety (Khasanah, 2019).

According to Cranney, Leman, Fergus, \& Rowatt (2018), anxiety is not pathological because it can be a source of strong motivation (Corey, 2015). Low anxiety is a positive effect on student learning performance and tends to increase learning motivation (Howard, 2020; Yang \& Quadir, 2018). In principle, anxiety is essential as it increases motivation and helps students achieve their set goals. Yanti, Erlamsyah, Zikra, \& Ardi (2013), stated that low-level academic anxiety tends to arouse students' enthusiasm to study. However, when anxiety is high, it leads to various physical and psychological disturbances.

Anxiety is a manifestation of mixed emotional processes, which occurs when students experience feelings of stress, frustration, and inner conflict(Palitz \& Kendall, 2020). It is also an unpleasant condition that includes fear, tension, worry, and confusion. Ifdil et al. (2019) stated that anxiety is one's feelings of fear or tension in dealing with learning problems. Anxious students think of learning as something that is not fun. According to Petrowski, Buehrer, Niedling, \& Schmalbach (2020)the symptoms of anxiety are reviewed through three, namely psychological components, such as nervousness, tension, insecurity, fear, and shock; physiological such as palpitations and cold sweat on the palms(Meriyati, Shaulita, \& Turnip, 2018); and social, which is associated with environmental factors in the form of behavior (attitude) and disturbance, and seclusion(Chardon, Janicke, Carmody, \& Dumont-Driscoll, 2016).

Many factors trigger the emergence of anxiety in students; these include: 1) high learning achievement outlined by the curriculum; 2) non-conducive learning climate; 3) assigning a lot of tasks; and 
4) a strict and unfair assessment system (Megawanti, 2015). According to Kusmaryono \& Ulia (2020), anxiety is also due to the unfriendly, fierce, rude, and less competent teachers' attitude towards students. The application of strict school discipline that prioritizes punishment, poor climate condition, and limited learning facilities and infrastructures, also trigger anxiety in students (Lestari, Latief, \& Widiastuti, 2013). Estonanto \& Dio (2019) stated that parents' expectation of children's abilitiesis also a contributing factor (Orji \& Oko, 2018; Stoet, Bailey, Moore, \& Geary, 2016).

The high intensity of learning anxiety creates various adverse effects on physical and psychological health. It also tends to affect their academics, thereby leading to low motivation, poor learning strategies, low self-esteem, negative self-evaluation, difficulty concentrating, and poor health perceptions (Mukhlis, Triaristina, Wahyudi, Kameliwati, \& Putri, 2020; Ramos et al., 2002). The high level of student anxiety has a negative impact on learning (Chanda \& Guha, 2018; Cooper \& Brownell, 2020; Downing, Cooper, Cala, Gin, \& Brownell, 2020), academic competition, self-confidence, self-acceptance, and self-concept (Anderson, 1999; Shabrina \& Rachmawati, 2019).

When students experience problems, their psychology tends to respond in accordance with the brain. These thoughts influences decisions and how to tackle problems(Idris \& Idris, 2019). Therefore, during such situations, efforts such as coping anxiety tend to have a positive influence on the individual and improve their ability to solve problems, regulate emotions, think more positively and accept oneself (Mukminina \& Abidin, 2020; Simpson, Lincoln, \& Ohannessian, 2020). Aysan, Thompson, \& Hamarat (2001), and Kumaraswamy (2013), stated that anxiety is strengthened until it is resolved. Therefore, this study aims to measure and analyze students' anxiety levels in learning and the efforts made to overcome this condition.Also, the efforts made by students, school personnel, and parents also play a role in directing their anxiety to be positive. Similarly, school counselors can make various preventive and curative efforts through various services to prevent or overcome anxiety in students.

\section{Method}

This is a quantitative descriptive study, with data collected from 192 students by measuring their anxiety aspects and efforts to overcome this condition. The aspects of anxiety measured are the frequency of participation, unpleasant communication experiences, self-avoidance, self-control, and self-expression. A total of 75 instrument items were appropriate to use because they were tested valid and reliable. In addition, the percentage formula was used for data analysis.

\section{Results and Discussions}

Figure 1 shows the learning anxiety of high school students in Seberang Ulu 2018/2019 academic year. The highest is in the normal category at $53.13 \%$ and with a frequency of 102 students. This is followed by a moderate category of $46.88 \%$ with a frequency of 90 students, and there isnone in the weight category.

According to Figure 1, most high school students' learning anxiety in Seberang Ulu is in the normal category. This is in accordance with their frequency of participation, unpleasant communication experiences, self-avoidance, self-control, and self-statements are presented in table 1. 


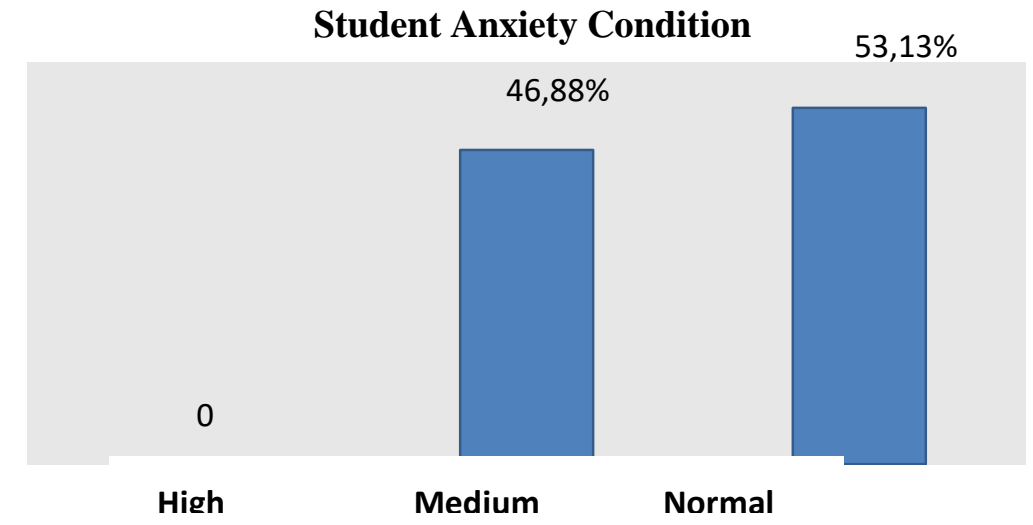

Figure 1: Student learning anxiety level

Table 1 shows that the highest anxiety frequency is in the normal category, with 110 students at $57.29 \%$. The unpleasant communication aspect is in the medium category, with a frequency of 113 at $58.85 \%$. Regarding self-avoidance, it is in the normal category, with a frequency of 116 students at $60.42 \%$. The highest aspect of student self-control anxiety is the normal category with a 98 at $51.04 \%$ frequency. In accordance with self-statement, students' anxiety was highest in the normal category, with a frequency of 116 at $60.42 \%$. When viewed from the weight category, the aspect of self-statement has the highest frequency of 7 , while the unpleasant communication experience aspect is 5 . The self-control aspect is 3 at a frequency of 2 students, and self-avoidance aspect of one.

Table 1: Aspects of frequency of student anxiety participation

\begin{tabular}{lccc}
\hline \multicolumn{1}{c}{ Aspects } & Category & Frequency & Percentage \\
\hline Participation Frequency & High & 2 & 1.04 \\
& Medium & 80 & 41.67 \\
& Normal & 110 & 57.29 \\
Unpleasant Communication & High & 5 & \\
Experience & Medium & 113 & 2.60 \\
& Normal & 74 & 58.85 \\
Self-Avoidance & High & 1 & 38.54 \\
& Medium & 75 & \\
& Normal & 116 & 0.52 \\
Self-Control & High & 39.06 \\
& Medium & 91 & 60.42 \\
Self-Statement & Normal & 98 & 1.56 \\
& & & 47.40 \\
& High & 7 & 51.04 \\
& Medium & 69 & 3.65 \\
& Normal & 116 & 35.94 \\
& & & 60.42 \\
\end{tabular}




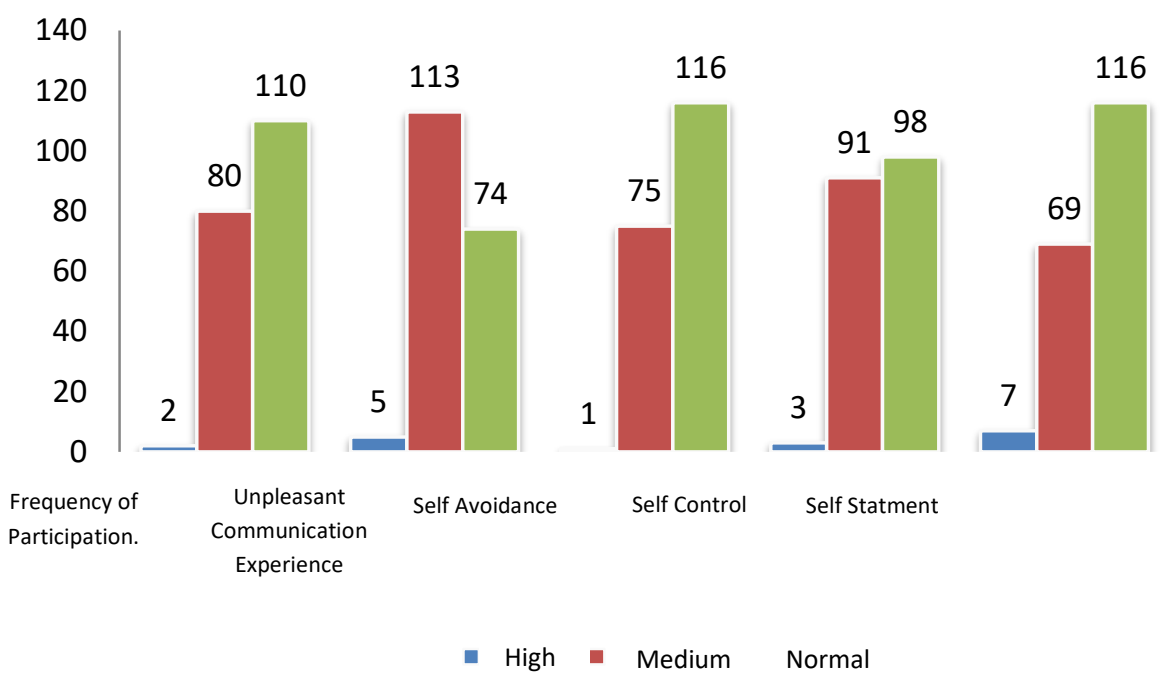

Figure 2: Conditions of student learning anxiety based on anxiety aspects

Figure 2 showed that from the five aspects, four had the highest anxiety and in the normal category. Furthermore, the frequency of participation, self-avoidance, self-control, and self-expression are also in the normal category. The aspect with the highest anxiety of 113 students is unpleasant communication experience. When viewed from the category of severe anxiety, self-statements, and unpleasant communication experiences, a high frequency of 7 and 5 students experience severe anxiety in these aspects.

Based on the efforts made in overcoming learning anxiety, it is found that the highest choice is choosing to confide in close friends, as shown in table 2.

Table 2: Efforts made by students in overcoming learning anxiety

\begin{tabular}{lcc}
\hline Efforts made by students & Frequency & Percentage \\
\hline Confide in with close friends & 22 & $11,45 \%$ \\
Ask a lot & 20 & $10,41 \%$ \\
Listen to songs & 19 & $9,89 \%$ \\
Confide with parents & 18 & $9,37 \%$ \\
Repeat the subject matter & 17 & $8,85 \%$ \\
Prayer & 17 & $8,85 \%$ \\
Make a study plan & 17 & $8,85 \%$ \\
Confide with a boyfriend & 13 & $6,77 \%$ \\
Join group study & 12 & $6,25 \%$ \\
Watching TV & 12 & $6,25 \%$ \\
Come to school counselor & 10 & $5,20 \%$ \\
Set playtime & 8 & $4,16 \%$ \\
Confide in brother & 7 & $3,64 \%$ \\
Play at the mall & 7 & $3,64 \%$ \\
Exercise & 7 & $3,64 \%$ \\
Play station & 6 & $3,25 \%$ \\
Confide in the homeroom teacher & 4 & $2,08 \%$ \\
Smoke & 4 & $2,08 \%$ \\
Pour it out by writing & 3 & $1,56 \%$ \\
Playing the guitar & 3 & $1,56 \%$ \\
Staying up late & 2 & $1,04 \%$ \\
\hline Total & 192 & $100 \%$ \\
\hline
\end{tabular}


Table 2 shows that the efforts made in overcoming their anxiety based on the 5 highest frequencies are as follows: $22(11.45 \%)$ chose to confide in their close friends, 20 (10.41\%) chose to ask questions, 19 $(9.89 \%)$ listened to songs, $18(9.37 \%)$ confided in parents, $17(8.85 \%)$ repeated the subject, while 10 $(5.20 \%)$ met the school counselor.

The result showed that student anxiety in learning is in the normal category at $53.13 \%$, with a frequency of 102 . It is also in the moderate category of $46.88 \%$, with a frequency of 90 students, with none in the weight category. This shows that the level of anxiety is still in the reasonable category and tends to motivate them to learn. Normal and moderate anxiety levels encourage learning, while high anxiety levels interfere with it (Daharnis et al., 2019). Elliott stated that low-level anxiety has a positive effect on student learning performance, while at a high level, it disrupts and worsens their behavior (Elliot \& McGregor, 1999).

Under normal or moderate conditions, anxiety is not pathological, because it can be a powerful motivational force. Yanti et al. (2013) stated that anxiety results from an awareness of responsibility. Student's learning anxiety determines their motivation in school (Alizamar et al., 2019; Corey, 2015). In principle, anxiety is important and tends to increase students' motivation in achieving their set goals. According to behavioral theory, when students are unable to control anxiety through rational ways, the ego relies on unrealistic ways(Cohen \& Kaplan, 2020). However, when they are able to overcome the symptoms, these feelings become a source of motivation, and the tense experienced is an incentive to carry out an activity.

Most student anxiety is in the normal and moderate category where the four aspects with the highest conditions are aspects of self-avoidance, self-control aspects, and self-expression. One aspect of the highest student anxiety is in the medium category, with a frequency of 113 students on unpleasant communication experience. However, 18 students experienced anxiety in the heavy category on the aspect of self-statement with the highest frequency with 7 students. Unpleasant communication self-control, frequency of participation, and self-avoidance were experienced by 5,2,3, and 1 person.

Anxiety is a person's feelings in the form of fear or tension in dealing with learning (Ifdil et al., 2019; Simpson et al., 2020). Students with anxiety analyze learning as a boring activity. This feeling arises because of several factors derived from personal experiences related to the teacher or taunts of friends. This leads to a negative influence on students and decreases their academic achievement (Cohen \& Kaplan, 2020; Elliot \& McGregor, 1999).

Anxiety is a useful stimulus used to solve problems (Yanti et al., 2013). The frequency of students that decided to reduce their anxiety by choosing to vent with close friends is 22 students at a percentage of $11.45 \%$. When students experience problems, psychology responds accordingly and influences the way they think and make decisions. Furthermore, students feel anxiety, when given workload that exceeds their capability (O'Rourke, Halpern, \& Vaysman, 2020). However, assuming they can control this anxiety condition, it strengthens and helps to resolve problems (Mukminina \& Abidin, 2020). However, cases of severe anxiety need to acquire handlers from experts such as school counselors. Therefore, preventive efforts are needed for school counselors to optimize guidance and counseling services (Hutagaol, 2020). Some of these efforts include counseling and extra-curricular activities (Ifdil, Hariko, Bariyyah, Zola, \& Amalianita, 2020; Wijaya, 2020). This means the availability of professional counselors in schools is absolutely needed.

\section{Conclusion}

Based on the study, it can be concluded that the anxiety of senior high school students in Seberang Ulu Palembang is in the normal category. In addition, the frequency of participation, self-avoidance, selfcontrol, and self-expression are normal. However, one aspect of the medium category is an unpleasant communication experience. Students tend to confide in close friends to overcome anxiety, and this has the highest frequency. In conclusion, parents and school counselors play a role in directing student anxiety to be positive with curative efforts to prevent and overcome this condition and enable development. 


\section{References}

Alizamar, A., Afdal, A., Ifdil, I., Ardi, Z., Ilyas, A., Zikra, Z., et al. (2019). Are there statistical anxiety differences between male and female students? Paper presented at the Journal of Physics: Conference Series.

Anderson, D. (1999). Coping with test anxiety. Florida: Gulf Coast University.

Aysan, F., Thompson, D., \& Hamarat, E. (2001). Test anxiety, coping strategies, and perceived health in a group of high school students: A Turkish sample. The Journal of genetic psychology, 162(4), 402-411.

Chanda, T., \& Guha, A. (2018). Effect of learning anxiety on ability in learning of higher secondary students. research journal of social sciences, $9(8)$.

Chardon, M. L., Janicke, D. M., Carmody, J. K., \& Dumont-Driscoll, M. C. (2016). Youth internalizing symptoms, sleep-related problems, and disordered eating attitudes and behaviors: A moderated mediation analysis. Eating behaviors, 21, 99-103.

Cohen, J. N., \& Kaplan, S. C. (2020). Understanding and Treating Anxiety Disorders: A Psychodynamic Approach Clinical Handbook of Anxiety Disorders (pp. 315-332): Springer.

Cooper, K. M., \& Brownell, S. E. (2020). Student anxiety and fear of negative evaluation in active learning science classrooms Active Learning in College Science (pp. 909-925): Springer.

Copeland, W. E., Adair, C. E., Smetanin, P., Stiff, D., Briante, C., Colman, I., et al. (2013). Diagnostic transitions from childhood to adolescence to early adulthood. Journal of Child Psychology and Psychiatry, 54(7), 791-799.

Corey, G. (2015). Theory and practice of counseling and psychotherapy: Nelson Education.

Cranney, S., Leman, J., Fergus, T. A., \& Rowatt, W. C. (2018). Hell anxiety as non-pathological fear. Mental Health, Religion \& Culture, 21(9-10), 867-883.

Daharnis, D., Nirwana, H., Ifdil, I., Afdal, A., Ardi, Z., Taufik, T., et al. (2019). Mathematics anxiety among prospective elementary school teachers and their treatment. Paper presented at the Journal of Physics: Conference Series.

Downing, V. R., Cooper, K. M., Cala, J. M., Gin, L. E., \& Brownell, S. E. (2020). Fear of Negative Evaluation and Student Anxiety in Community College Active-Learning Science Courses. $C B E-$ Life Sciences Education, 19(2), ar20.

Efrila, M. (2020). Pelaksanaan Layanan Konseling Kelompok dengan Pendekatan Behavioral untuk Mengatasi Kecemasan Siswa di Sekolah Madrasah Tsanawiyah Darel Hikmah Pekanbaru. Universitas Islam Negeri Sultan Syarif Kasim Riau.

Elliot, A. J., \& McGregor, H. A. (1999). Test anxiety and the hierarchical model of approach and avoidance achievement motivation. Journal of Personality and social Psychology, 76(4), 628.

Estonanto, A. J. J., \& Dio, R. V. (2019). Factors causing Mathematics Anxiety of Senior High School Students in Calculus. Asian Journal of Education and e-Learning (ISSN: 2321-2454), 7(01).

Friedman, N. P., Miyake, A., Altamirano, L. J., Corley, R. P., Young, S. E., Rhea, S. A., et al. (2016). Stability and change in executive function abilities from late adolescence to early adulthood: A longitudinal twin study. Developmental psychology, 52(2), 326.

Howard, E. (2020). A review of the literature concerning anxiety for educational assessments.

Hutagaol, T. (2020). Penanganan Kasus Kecemasan Sosial Siswa dalam Layanan Bimbingan dan Konseling (Studi Kasus di Sekolah Menengah Kejuruan Muhammadiyah 3 Terpadu Pekanbaru). Universitas Islam Negeri Sultan Syarif Kasim Riau.

Idris, I., \& Idris, I. (2019). Emotional Freedom Technique Dalam Mengatasi Kecemasan Siswa Menghadapi Ujian. Tadbir: Jurnal Manajemen Pendidikan Islam, 7(2), 106-115.

Ifdil, I., Fadli, R. P., Zola, N., Erwinda, L., Sari, A., Churnia, E., et al. (2019). Chromotherapy: An alternative treatment for mathematics anxiety among elementary school students. Paper presented at the Journal of Physics: Conference Series.

Ifdil, I., Hariko, R., Bariyyah, K., Zola, N., \& Amalianita, B. (2020). Evaluation of the understanding of School Counselors on Individual Counseling Process in Indonesia.

Khasanah, W. N. (2019).

Hubungan Antara Efikasi Diri Dan Partisipasi Siswa Mengikuti Konseling Kelompok Dengan Kecemasan Ujian Akhir Di Sman Sokaraja. Universitas Negeri Semarang. 
Kumaraswamy, N. (2013). Academic stress, anxiety and depression among college students: A brief review. International review of social sciences and humanities, 5(1), 135-143.

Kusmaryono, I., \& Ulia, N. (2020). Interaksi Gaya Mengajar dan Konten Matematika sebagai Faktor Penentu Kecemasan Matematika. Mosharafa: Jurnal Pendidikan Matematika, 9(1), 143-154.

Lestari, Y., Latief, S., \& Widiastuti, R. (2013). Mengurangi Kecemasan Siswa Di Sekolah Dengan Menggunakan Teknik Desensitisasi Sistematis. ALIBKIN (Jurnal Bimbingan Konseling), 2(3).

Megawanti, P. (2015). Meretas Permasalahan Pendidikan Di Indonesia. Formatif: Jurnal Ilmiah Pendidikan MIPA, 2(3).

Meriyati, M., Shaulita, R., \& Turnip, L. N. (2018). Problem Based Learning Strategy: the Impact on Mathematical Learning Outcomes viewed from Anxiety Levels. Al-Jabar: Jurnal Pendidikan Matematika, 9(2), 199-208.

Mukhlis, H., Triaristina, A., Wahyudi, D. A., Kameliwati, F., \& Putri, R. H. (2020). Anxiety Confronts Practice Exam Reviewed from Optimism, Emotional Intelligence, and Social Support on Student of STIKES. Journal of Talent Development and Excellence, 12(2s), 830-842.

Mukminina, M., \& Abidin, Z. (2020). Coping Kecemasan Siswa SMA dalam Menghadapi Ujian Tulis Berbasis Komputer (UTBK) Tahun 2019. JURNAL Al-AZHAR INDONESIA SERI HUMANIORA, 5(3), 110-116.

Network, N. E. C. C. R. (2005). Child care and child development: Results from the NICHD study of early child care and youth development: Guilford Press.

O'Rourke, E. J., Halpern, L. F., \& Vaysman, R. (2020). Examining the relations among emerging adult coping, executive function, and anxiety. Emerging Adulthood, 8(3), 209-225.

Orji, E. U., \& Oko, F. O. C. (2018). Predictive Relationships of Parenting Style and Role of Students SelfEfficacy on Examination Anxiety among O'level Students in Afikpo North LGA. The Melting Pot, $4(1)$.

Palitz, S. A., \& Kendall, P. C. (2020). Anxiety Disorders in Children Clinical Handbook of Anxiety Disorders (pp. 141-156): Springer.

Petrowski, K., Buehrer, S., Niedling, M., \& Schmalbach, B. (2020). The effects of light exposure on the cortisol stress response in human males. Stress, 1-7.

Ramos, A., Kangerski, A. L., Basso, P. F., Santos, J. E. D. S., Assreuy, J., Vendruscolo, L. F., et al. (2002). Evaluation of Lewis and SHR rat strains as a genetic model for the study of anxiety and pain. Behavioural brain research, 129(1-2), 113-123.

Shabrina, N. B. U., \& Rachmawati, M. A. (2019). Husnudzan and Anxiety in Students Dealing with National Examination.

Simpson, E. G., Lincoln, C. R., \& Ohannessian, C. M. (2020). Does Adolescent Anxiety Moderate the Relationship between Adolescent-Parent Communication and Adolescent Coping? Journal of Child and Family Studies, 29(1), 237-249.

Stoet, G., Bailey, D. H., Moore, A. M., \& Geary, D. C. (2016). Countries with higher levels of gender equality show larger national sex differences in mathematics anxiety and relatively lower parental mathematics valuation for girls. PLoS ONE, 11(4).

Wijaya, F. (2020). Bimbingan Konsling Islamiperspektif Bibliotheraphy dalam Mengatasi Gangguan Kecemasan siswa Di MA NW Apitaik. At-Tadbir: Jurnal Manajemen Pendidikan Islam, 4(1), 32-47.

Yang, J. C., \& Quadir, B. (2018). Effects of prior knowledge on learning performance and anxiety in an English learning online role-playing game. Journal of Educational Technology \& Society, 21(3), 174185.

Yanti, S., Erlamsyah, E., Zikra, Z., \& Ardi, Z. (2013). Hubungan antara Kecemasan dalam Belajar dengan Motivasi Belajar Siswa. Konselor, 2(1). 